\title{
Species composition and community structure of pelagic nekton off Oregon and Washington under variable oceanographic conditions
}

\author{
Richard D. Brodeur ${ }^{1, *}$, Joseph P. Fisher ${ }^{2}$, Robert L. Emmett ${ }^{1}$, Cheryl A. Morgan ${ }^{3}$, \\ Ed Casillas ${ }^{4}$
}

\footnotetext{
${ }^{1}$ Northwest Fisheries Science Center, NOAA Fisheries, 2030 S. Marine Science Drive, Newport, Oregon 97365, USA

${ }^{2}$ College of Ocean and Atmospheric Sciences, Oregon State University, 104 COAS Admin. Building, Corvallis, Oregon 97331, USA

${ }^{3}$ Cooperative Institute for Marine Resources Studies, Oregon State University, 2030 S. Marine Science Drive, Newport, Oregon 97365, USA
}

${ }^{4}$ Northwest Fisheries Science Center, NOAA Fisheries, 2725 Montlake Blvd. E., Seattle, Washington 98112, USA

\begin{abstract}
Dramatic changes in the physical and biological conditions off Washington and Oregon, USA, have occurred since 1998, including extreme El Niño (warm) and La Niña (cool) years, high and low Columbia River flow years, a major intrusion of subarctic water, and a low oxygen event on the shelf. The occurrence of contrasting environmental conditions provided an excellent opportunity to examine pelagic nekton distributions and their abiotic and biotic associations. Pelagic surface trawl surveys conducted during June and September from 1998 to 2002 off northern Washington to central Oregon revealed a nekton community dominated by Pacific herring (33.5\% of total catch), Pacific sardines $(29.9 \%)$, and northern anchovy (12.3\%). Between 1998 and 2002, species composition shifted from a community dominated by southern species (mackerels and hake) to one dominated by northern species (squid, smelts, and salmon), but the transition was gradual, and small pelagic species (sardines, herring, and anchovy) showed no consistent trends in abundance over time. Species diversity/evenness was highest in September 2002. Cluster analysis identified 7 species and 6 station clusters. Subyearling Chinook salmon, market squid, Pacific sardine, yearling coho salmon, and Pacific saury were the strongest indicator species for 5 of these cluster groups. Cluster group distributions differed between both inshore/offshore and north/south. A 3-dimensional ordination explained $55 \%$ of the total variance with bottom depth, distance from shore, and sea-surface temperature correlated with the first axis, latitude with the second axis, and surface salinity, surface density and stability with the third axis. Our results suggest that the habitats occupied by pelagic nekton species expand and contract in relation to the dynamic nature of the California Current and are affected by changing ocean conditions at both seasonal and interannual periodicities.
\end{abstract}

KEY WORDS: Pelagic nekton · Assemblages · Habitat - Coastal upwelling · Multivariate analyses · North Pacific Ocean · Juvenile salmon

Resale or republication not permitted without written consent of the publisher

\section{INTRODUCTION}

The California Current ecosystem is recognized to be highly variable on seasonal, interannual, and decadal time scales (Brodeur et al. 1996, McGowan et al. 1998, Chavez et al. 2003). In addition to large-scale decadal processes that affect the entire North Pacific (e.g. Pacific Decadal Oscillation; Mantua et al. 1997,
Miller et al. 2004), the northern region of the California Current off Oregon and Washington, USA, lies at the intersection of Subarctic and Transition Zone water masses. It is thus affected by oceanographic processes occurring both north and south of the region, and is further mediated by oceanic and continental influences (Hickey 1998, Hickey \& Banas 2003). Anomalous events, such as El Niños or La Niñas, affect the compo- 
sition and production of all trophic levels in this region (Pearcy et al. 1985, Pearcy \& Schoener 1987, Chavez et al. 2002, Pearcy 2002, Peterson et al. 2002, Peterson \& Schwing 2003) as well as the structure of the pelagic food web (Brodeur \& Pearcy 1992).

In particular, the last half-decade (1998 to 2002) has witnessed extreme variability in oceanographic conditions off Oregon on a magnitude that has not been recorded previously (Peterson \& Schwing 2003). For example, one of the strongest El Niño events ever recorded occurred in late 1997 and 1998 and was followed by an extremely strong La Niña in 1999 (Chavez et al. 2002, Schwing et al. 2002). It has now been suggested that a major regime shift also occurred in 1999 associated with the La Niña that returned the eastern North Pacific to a cool state not observed since the mid-1970s (Peterson \& Schwing 2003). Other recent anomalies in this region included a major drought in 2001, which decreased freshwater input into the coastal zone to record low levels, and an intrusion of nutrient-rich subarctic water and subsequent high phytoplankton production which led to anoxic conditions off Oregon by late summer 2002 (Freeland et al. 2003, Wheeler et al. 2003, Grantham et al. 2004).

Pelagic nekton may be useful indicators and integrators of changing oceanographic conditions because they are able to migrate quickly into preferred habitats, and, in the case of smaller pelagic species, respond by pronounced fluctuations in recruitment over relatively short time intervals. Annual variations in the ocean environment may be reflected in changes in both the distributions of adult pelagic fishes and the timing and location of spawning. Previous studies (Brodeur \& Pearcy 1986, 1992, Emmett \& Brodeur 2000, Brodeur et al. 2003a) have shown substantial seasonal and interannual changes in abundance and distribution of many pelagic nekton species. However, changes in the community structure of nekton have been documented only for individual years (Brodeur et al. 2003b, 2004) but not within years or between years of contrasting oceanographic conditions.

In this study, we use a combination of descriptive and multivariate techniques (Field et al. 1982, Clarke \& Warwick 2001) including diversity indices, cluster analysis, indicator species analysis, and nonmetric multidimensional scaling (NMS), an ordination technique, to study near-surface nekton communities off northern Oregon and Washington. In particular, we are interested in the associations of juvenile salmon with other nekton. These species may be predators on salmon, competitors with salmon, or alternate prey for predators that might otherwise eat salmon. This time period exhibited large fluctuations in salmon survival reflected in both low and record high salmon survival along the West Coast that appeared to be linked to oceanographic changes (Logerwell et al. 2003, Scheuerell \& Williams 2005). We are also interested in how nektonic communities respond to abrupt changes in their physical and biological environment with a view toward understanding how future environmental changes will affect the pelagic ecosystem in the northern California Current.

\section{MATERIALS AND METHODS}

Sampling. Pelagic nekton were collected during NOAA Fisheries pelagic trawl surveys for juvenile salmonids off Washington and Oregon during June and September from 1998 through 2002. We sampled along 5 to 10 east-west transect lines located between La Push, Washington, and Cape Perpetua, Oregon (Fig. 1). Sampling consisted of 30 min surface tows

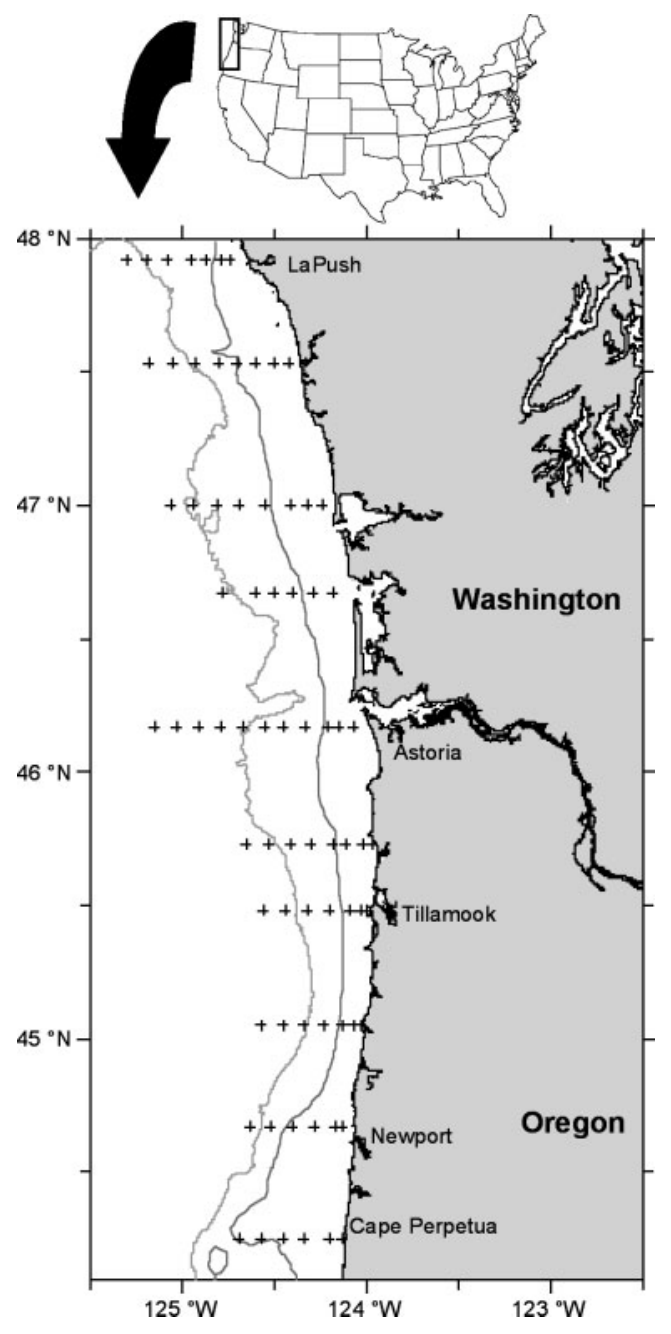

Fig. 1. Locations of sampling stations along transects off the Washington and Oregon coasts sampled during June and September, 1998-2002. Also shown are the $100 \mathrm{~m}$ and $180 \mathrm{~m}$ depth contours 
with a pelagic rope trawl at a speed over ground of approximately $6 \mathrm{~km} \mathrm{~h}^{-1}$. The $108 \mathrm{~m}$ long rope trawl contained variable mesh sizes $(162.6 \mathrm{~cm}$ at mouth to $8.9 \mathrm{~cm}$ at cod end) and had a mouth opening of $30 \mathrm{~m}$ wide by $20 \mathrm{~m}$ deep, with the head rope at about $1 \mathrm{~m}$. To retain catches of small nekton, a $6.1 \mathrm{~m}$ long, $0.8 \mathrm{~cm}$ knotless liner was sewn into the cod end. Chartered commercial fishing vessels and a fisheries research vessel (RV 'W. E. Ricker') were used to conduct the sampling. Trawls were conducted at 6 to 8 stations on each transect from the shallowest bottom depth possible $(\sim 30 \mathrm{~m}$ depth) out to approximately $50 \mathrm{~km}$ from shore, often extending beyond the continental shelf.

From the available collections, we excluded samples from some stations over concerns of potential bias. First, only 'regular' station hauls at predetermined locations were included, and several opportunistic or special studies hauls were excluded. Due to potential diel differences in vertical distribution and catchability of many nekton (e.g. Emmett et al. 2004, Krutzikowsky \& Emmett 2005), we restricted our analyses to daytime hauls. Any haul occurring completely (or almost completely) between the beginning of morning civil twilight and the end of evening civil twilight was considered a 'day' haul. Hauls outside of this time window were eliminated, leaving 430 samples for analyses.

The total number of each nekton species caught in each haul was either determined directly or estimated from the total weight of the species in a catch and the weight and number of individuals in a subsample of that catch. In addition, length data were collected for all salmonids and for subsamples of all other species caught. Most nekton were identified to species, but small juvenile specimens were sometimes classified at higher taxonomic levels (genus or family). Although some larval forms were collected, we analyzed only those taxa that were likely to be true nekton (late juvenile and adult stages) and quantitatively retained by the mesh size we used. Temperature, salinity, and density to within $5 \mathrm{~m}$ of the bottom or a depth of $100 \mathrm{~m}$ were measured with a CTD at each station. Water transparency was measured using a Secchi disc. Chlorophyll $a$ and nutrient samples were collected from $3 \mathrm{~m}$ depth using a Niskin bottle. In the laboratory, chlorophyll was calculated from fluorescence measurements. Phosphate $\left(\mathrm{PO}_{4}\right)$, silicate $\left(\mathrm{Si}(\mathrm{OH})_{4}\right)$, nitrate $\left(\mathrm{NO}_{3}\right)$, nitrite $\left(\mathrm{NO}_{2}\right)$, and ammonium $\left(\mathrm{NH}_{4}\right)$ concentrations were determined in the nutrient samples by the University of Washington (Seattle) Marine Chemistry Lab using standard methods adapted for an autoanalyzer.

Species diversity and dominance indices. For these analyses, we used the full data set of species $(n=72)$ to calculate species composition and diversity. We used 3 indices to assess differences between cruises. As a diversity measurement we used both the ShannonWeiner index $\left(H^{\prime}\right)$ and Simpson index $(1-\lambda)$, which measures both species number (richness) and equitability (evenness). Both indices increase with increasing diversity. We used Pielou's index $(E)$ to measure evenness; this index ranges from 0 to 1.0 with the maximum value occurring when all taxa are equally abundant (Magurran 1988).

Multivariate analysis. The categories in each sampling unit were different species of fishes and squids and different age groups of salmonid fishes. We distinguished the juvenile age classes (subyearling and yearling) of salmon from the adults, because migratory patterns and habitat preferences can be quite distinct for the different life history stages. We grouped salmon into different age-classes based on fork length and predetermined fork-length ranges for the different age-classes during different months. This method was very accurate for coho salmon, but was less accurate, although still useful, for Chinook salmon since subyearling and yearling individuals overlap slightly in their size distributions (J. Fisher unpubl. data). In order to reduce the distorting effects on the analyses of very large catches of any species, abundances in sample units (no. $\mathrm{km}^{-1}$ towed +1 ) were $\log _{10}$-transformed. Species that occurred in less than $2.5 \%$ of sample units were also excluded, as were hauls with no common species, leaving a matrix of 387 hauls by 27 species for the 10 cruises. The software PC-ORD (McCune \& Mefford 1999) was used for all multivariate methods.

In order to define months and years for which species composition was similar, an initial cluster analysis of species abundance was done across the 10 cruises pooled together. In this initial cluster analysis, species abundance was expressed as the average across all hauls of a cruise of $\log _{10}$ (no. ind. $\mathrm{km}^{-1}$ towed +1 ), resulting in a matrix of 10 sample units (cruises) by 27 species. All subsequent multivariate analyses used individual hauls as the sampling units and the full matrix ( 387 hauls by 27 species), which included data from all 10 cruises.

Cluster analyses of both sampling units (hauls) and of species (on the transposed matrix) used a hierarchical agglomerative clustering strategy, Sørensen (BrayCurtis) distances, and the Flexible-Beta $(\beta=-0.25)$ linkage method. Cluster dendrograms were cut where the resulting cluster groups were ecologically interpretable, at the level where $13 \%$ of information remained for the sample clusters and at $30 \%$ of information remaining for the species clusters.

Species that were representative of the different sample clusters were identified using Indicator Species Analysis (Dufrene \& Legendre 1997). Indicator values (IV) were calculated for each species $(j)$ and cluster group $(k)$ : 


$$
\mathrm{IV}=100\left(\mathrm{RA}_{k j} \times \mathrm{RF}_{k j}\right)
$$

where $\mathrm{RA}_{k j}=$ the average abundance of species $j$ in group $k$ relative to its average abundance in the other groups, and $\mathrm{RF}_{k j}=$ the relative frequency of occurrence of species $j$ in group $k$. For each species, the cluster group for which its IV was strongest $\left(\mathrm{IV}_{\max }\right.$ ) was identified. The statistical significance of each $\mathrm{IV}_{\max }$ was tested by Monte Carlo randomization, in which sample units were randomly reassigned to cluster groups 1000 times and $\mathrm{IV}_{\max }$ was recalculated for each species and each randomization. The probability that a species had no statistical value as an indicator for a cluster group was equal to the proportion of its $\mathrm{IV}_{\max }$ from the randomizations that was larger than the $\mathrm{IV}_{\max }$ resulting from the cluster analysis.

The matrix was transposed and a clustering of species was performed to examine which species had similar distributions among the hauls. When clustering species, it is recommended that the species abundance data be relativized (McCune \& Grace 2002). For this cluster analysis we expressed the abundance of each species in each haul as a proportion of the total catch of that species in all hauls during all cruises of the study (relativizing by species totals). Species that are similar to each other in their distributions among the sampling units should tend to cluster together. Species clusters were then compared with the indicator species for the different sample clusters to see if they were similar.

We used NMS, an ordination technique (Clarke \& Warwick 2001), to examine structure of sample units (fish hauls) in species space (Kruskal 1964). Distances between samples in species space were measured using the Sørensen (Bray-Curtis) distance measure (McCune \& Grace 2002). A single ordination was performed on the hauls by species matrix (387 hauls $\times 27$ species) that included data from all June and September cruises. Based on the decrease in stress (lack of fit) with the addition of each ordination axis, a 3-dimensional solution was most effective for explaining variation in the original multi-dimensional species space.

In order to describe the environmental gradients associated with the NMS ordination axes, the temperature $\left({ }^{\circ} \mathrm{C}\right)$, salinity (psu), and density $\left(\sigma_{\mathrm{T}}\right)$ at $1 \mathrm{~m}$ depth, stability [(density $\left.\left.{ }_{(20 \mathrm{~m})}-\operatorname{density}_{(1 \mathrm{~m})}\right) / 19 \mathrm{~m}\right]$, station bottom depth $(\mathrm{m})$, distance from shore (nautical miles, $\mathrm{n}$ miles), latitude (decimal degrees), chlorophyll $\left(\mu \mathrm{g} \mathrm{l}^{-1}\right)$, nutrient concentrations $(\mu \mathrm{M})$, and transparency (Secchi depth in $\mathrm{m}$ ) during the different hauls were correlated with the ordination scores along each axis. Ordination axes were rotated to maximize the correlation of distance from shore with one of the axes. Due to the large sample size, many relatively small correlation coefficients were found to be statistically significant at the $\mathrm{p}=0.05$ level (see McCune \& Grace 2002). Thus, we used a more conservative p-value of 0.01 , which corresponds to an r-value of 0.20 being significant.

\section{RESULTS}

\section{Environmental conditions}

Spring (April and May) upwelling was near or slightly below the long-term (1946-1997) average during most years, but upwelling was anomalously high in June, August, and September 1998, September 1999, July 2001 and July and August 2002. Averaged over the entire spring and summer, upwelling was strongest in 1998 and weakest in 2000 (Fig. 2A). Columbia River flows showed more consistent patterns by year, with 1998 (except April) and 1999 above the 1992 to 2002 mean flow and with the drought year of 2001 persistently below average flows (Fig. 2B).
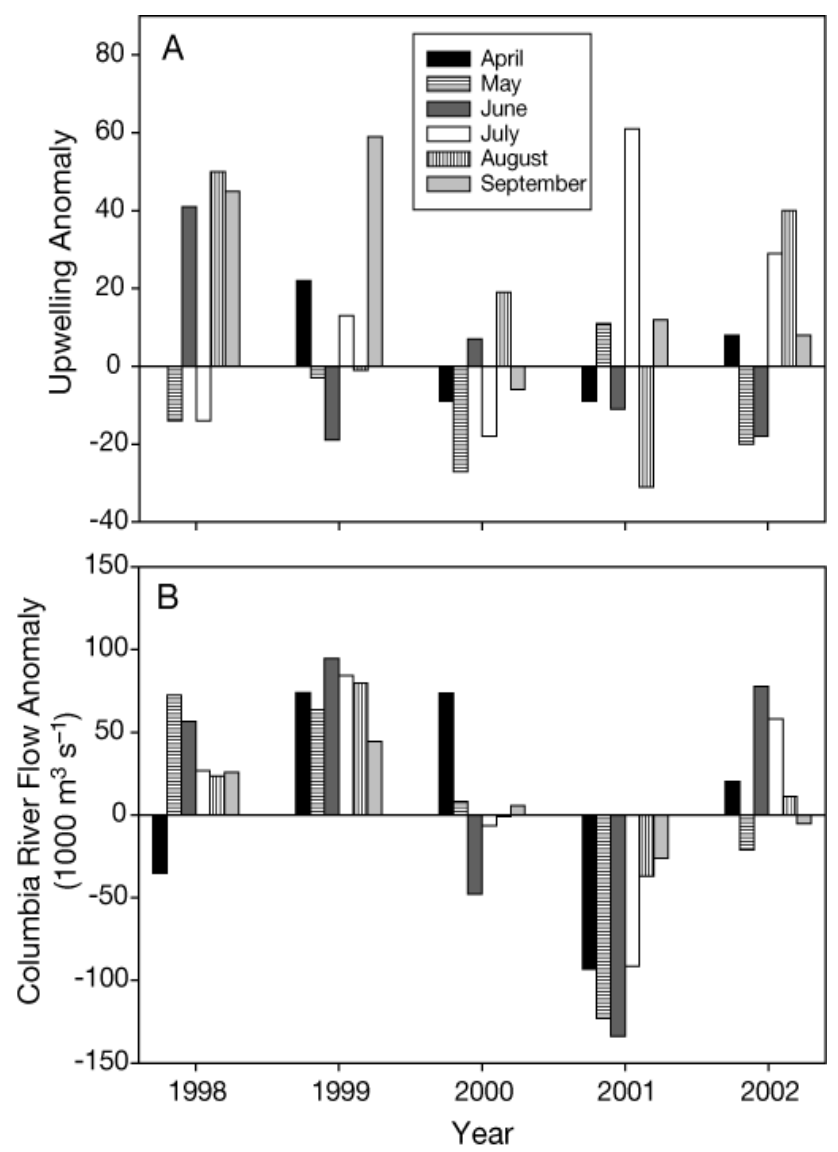

Fig. 2. (A) Monthly upwelling anomalies at $45^{\circ} \mathrm{N}$ from April through September of 1998 through 2002 relative to the longterm monthly average calculated from 1946-1997 (data from www.pfeg.noaa.gov). (B) Monthly Columbia River flow anomalies taken at the United States Geological Survey station at Quincy, Oregon, from April through September of 1998 through 2002 relative to the 1991-2002 monthly average (http://waterdata.usgs.gov/nwis/) 
June sea-surface temperatures were relatively warm in 1999 and 2002, with areas of cooler temperature generally near the coast during all years (Fig. 3A). In September, temperatures were generally warmer offshore and cooler on the coast, although 2000 showed a distinct latitudinal gradient, with cooler water found only off Central Oregon (Fig. 3B). The Columbia River plume, distinguished by the presence of low-salinity surface water, was moderately well developed in June 1999, 2000, and 2002 but almost completely absent in June 2001 (Fig. 3A). In September, the Columbia River plume was apparent during 1998, 2000, and 2001 but was absent or very weak in 1999 and 2002 (Fig. 3B).

\section{Catch composition}

The pelagic nekton community off Oregon and Washington was numerically dominated by relatively few species. The top 12 species comprised $80.5 \%$ of the total nekton abundance. Several pelagic schooling species such as Pacific herring (33.5\% of total), Pacific sardines $(29.9 \%)$, and northern anchovy (12.3\%) were the most dominant overall (Fig. 4A). Other species, such as market squid, coho and Chinook salmon, whitebait smelt, and Pacific saury, were of secondary importance during some cruises (Fig. 4B). Total abundances varied seasonally and interannually with high-
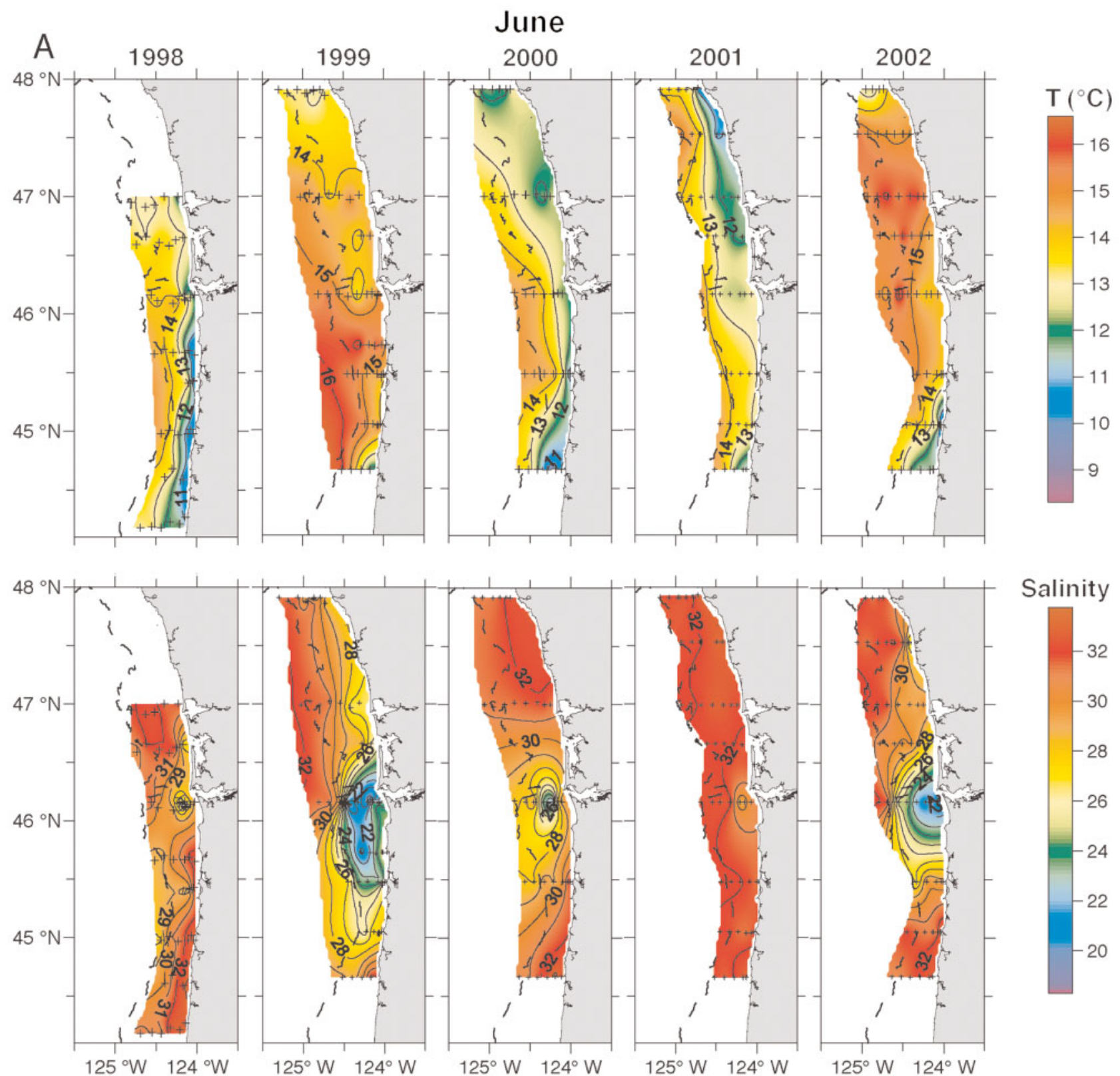

Fig. 3. Surface $(1 \mathrm{~m})$ temperatures and salinities measured during (A) June and (B) September of each year (continued on next page) 

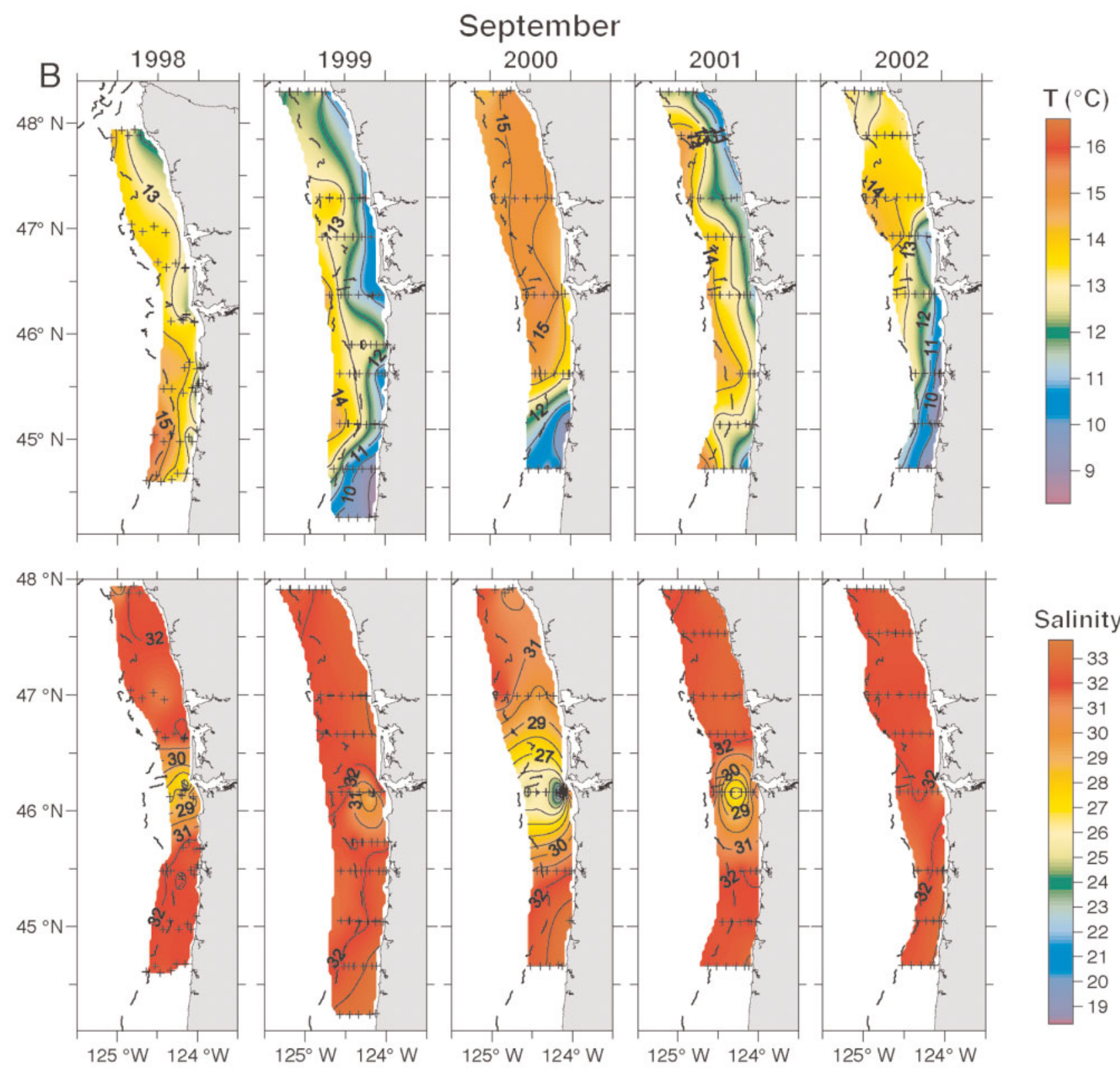

Fig. 3 (continued)

est catches in September 1999, June 2000, and June 2002 (Fig. 4). The September 1999 cruise had the highest abundance of the dominant species, mainly due to high catches of Pacific sardine and Pacific herring, whereas the September 2002 survey had the lowest overall abundance and was dominated by Chinook salmon, herring, and Pacific saury. The June 2000 cruise showed a particular dominance of northern anchovy. Although the average catch per unit effort of Pacific herring, Pacific sardine, and northern anchovy was often high (Fig. 4A), the frequency of occurrence of these species in the hauls was relatively low (Table 1), reflecting the schooling behavior of these species and their patchy distributions. The high aver- age abundance of these species was often the result of very large catches in a few hauls.

Coho and Chinook salmon were caught during all cruises in relatively low numbers (Fig. 4B), but often occurred in a relatively high percentage of hauls (Table 1). Pacific hake was only abundant in June 1998, and chub mackerel in June 1998 and September 1999 (Fig. 4B). Pacific saury was more abundant in September than in June and first occurred in September 2000 (Fig. 4B).

Some species near the northern end of their distribution in our sampling area (Pacific sardine, chub mackerel, Pacific hake, and whitebait smelt) occurred more frequently in hauls in June 1998 during a strong El 


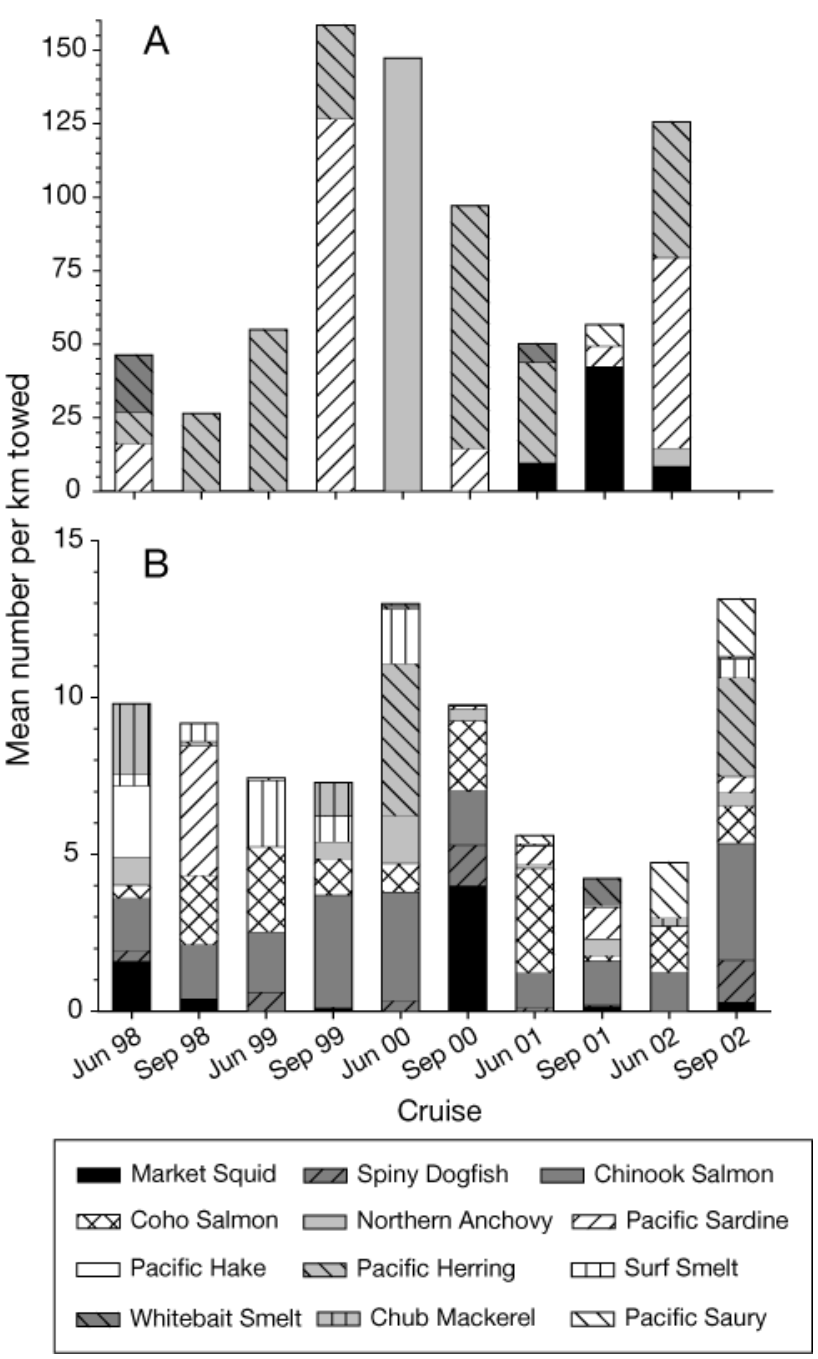

Fig. 4. Mean abundance $\mathrm{km}^{-1}$ towed of the dominant 12 nekton species by cruise for (A) species which were represented by catches $>5$ fish $\mathrm{km}^{-1}$ towed and (B) species represented by $\leq 5$ fish $\mathrm{km}^{-1}$ towed. All age classes of Chinook and coho salmon are combined for this figure. No species were caught at densities $>5$ fish $\mathrm{km}^{-1}$ in September 2002

Niño than during any subsequent cruise (Table 1). Although chub mackerel, Pacific hake, and whitebait smelt were numerically most abundant in June 1998, Pacific sardine was actually more abundant in 2 later cruises and showed no consistent pattern during these 5 years (Fig. 4A). Furthermore, frequency of occurrence of species that reproduce in the region or tend to have more northern affinities (market squid, surf smelt, Pacific herring, northern anchovy, and salmon) was not unusually low in June 1998 and showed no consistent trends among years (Table 1). Diversity and evenness were high in June 1998 but low in September of that year. September measures tended to increase in succeeding years except for 1999 (Table 2).

\section{Multivariate analysis}

The cluster dendrogram of cruises (a 10 cruise by 27 species matrix) revealed strong seasonal effects. All June cruises (except 1998) clustered together, with June 2001 and 2002 showing very similar species composition (Fig. 5A). The June 1998 nekton community was most similar to the September communities, especially September 1998, possibly due to the effects of the strong El Niño that year. A similar analysis using the original matrix, which included all rare species, yielded similar results (not shown). In that analysis, September 2002 formed its own group owing to the occurrence of several rare taxa captured only during that cruise.

Cutting the species cluster dendrogram for the transposed full matrix (27 species by 387 hauls) with about $30 \%$ information remaining resulted in 7 species cluster groups (A to G, Fig. 5B). The cluster analysis of species showed a high degree of association for some salmon species with each other and with other taxa (Fig. 5B). In particular, subyearling Chinook salmon were associated with surf smelt, American shad, starry flounder and Pacific herring (cluster G). Yearling Chinook and coho salmon and adult Chinook and coho salmon also clustered together (cluster D) as did juvenile chum and sockeye salmon (cluster F). Other notable associations included northern anchovy, Pacific hake, whitebait smelt, and Pacific sanddab (cluster A), Pacific sardine and chub mackerel (cluster $\mathrm{C}$ ), and jack mackerel, blue shark, ocean sunfish, Pacific saury, and juvenile sablefish (cluster B) (Fig. 5B).

Cutting the sample cluster dendrogram for the full data set (387 hauls by 27 species) with $13 \%$ information remaining resulted in 6 sample groups. Indicator values of the different species for the different cluster groups ( $p<0.05$ in bold) are shown in Table 3 . Of the 27 taxa, 22 were significant indicators of at least 1 group, and all but cluster group 2 had at least 1 significant indicator species. Some species, notably yearling and adult Chinook salmon and adult coho salmon showed similar affinities to all the cluster groups (except 6) and were not determined to be an indicator species of any 1 cluster (Table 3). These indicator species groups were similar to the cluster species groups for the different sample clusters (Table 3, Fig. 5B). Species clusters A and G comprised mainly species that were significant indicators for sample cluster 1 , and species clusters B, C, and E comprised mainly species that were significant indicators for sample clusters 6,4 , and 3, respectively. Species clusters D and F comprised mainly salmon, some of which were significant indicators for sample cluster 5 (Fig. 5B).

Maps showing the geographic distributions of the sample cluster groups in each cruise are shown in 
Table 1. Percent frequency of occurrence of the 27 most frequent species/life history stages by cruise used in the multivariate analyses. Chinook and coho salmon are separated by life history stage. s: subyearling; y: yearling; a: subadult or adult

\begin{tabular}{|c|c|c|c|c|c|c|c|c|c|c|c|}
\hline Common name & Scientific name & Jun 98 & Sep 98 & Jun 99 & Sep 99 & Jun 00 & Sep 00 & Jun 01 & Sep 01 & Jun 02 & Sep 02 \\
\hline Market squid & Loligo opalescens & 40 & 10 & 34 & 6 & 21 & 0 & 21 & 36 & 47 & 17 \\
\hline Spiny dogfish & Squalus acanthias & 20 & 10 & 14 & 12 & 7 & 0 & 8 & 11 & 13 & 13 \\
\hline Soupfin shark & Galeorhinus zyopterus & 10 & 0 & 0 & 4 & 11 & 0 & 0 & 0 & 11 & 2 \\
\hline Blue shark & Prionace glauca & 5 & 2 & 0 & 2 & 0 & 0 & 31 & 9 & 2 & 9 \\
\hline American shad & Alosa sapidissima & 8 & 5 & 0 & 4 & 4 & 0 & 6 & 2 & 4 & 0 \\
\hline Pacific herring & Clupea pallasi & 43 & 19 & 16 & 34 & 18 & 14 & 17 & 34 & 17 & 43 \\
\hline Pacific sardine & Sardinops sagax & 40 & 19 & 10 & 30 & 21 & 18 & 19 & 18 & 23 & 19 \\
\hline Northern anchovy & Engraulis mordax & 25 & 17 & 8 & 10 & 21 & 4 & 13 & 21 & 13 & 38 \\
\hline Chinook salmon (s) & Oncorhynchus tshawytscha & 25 & 24 & 8 & 50 & 29 & 29 & 13 & 32 & 38 & 51 \\
\hline Chinook salmon (y) & Oncorhynchus tshawytscha & 33 & 14 & 60 & 24 & 50 & 32 & 27 & 18 & 53 & 36 \\
\hline Chinook salmon (a) & Oncorhynchus tshawytscha & 33 & 12 & 20 & 8 & 36 & 11 & 29 & 16 & 38 & 26 \\
\hline Coho salmon (y) & Oncorhynchus kisutch & 25 & 19 & 62 & 30 & 46 & 68 & 67 & 39 & 62 & 34 \\
\hline Coho salmon (a) & Oncorhynchus kisutch & 15 & 5 & 10 & 8 & 36 & 18 & 35 & 46 & 40 & 28 \\
\hline Chum salmon & Oncorhynchus keta & 0 & 2 & 8 & 10 & 4 & 11 & 40 & 5 & 34 & 9 \\
\hline Pink salmon & Oncorhynchus nerka & 0 & 0 & 0 & 0 & 0 & 7 & 0 & 0 & 0 & 19 \\
\hline Sockeye salmon & Oncorhynchus gorbuscha & 0 & 0 & 4 & 0 & 4 & 4 & 17 & 0 & 8 & 0 \\
\hline Surf smelt & Hypomesus pretiosus & 8 & 0 & 0 & 16 & 11 & 0 & 4 & 5 & 11 & 2 \\
\hline Whitebait smelt & Allosmerus elongatus & 20 & 19 & 0 & 2 & 0 & 0 & 2 & 7 & 0 & 2 \\
\hline Pacific hake & Merluccius productus & 33 & 10 & 4 & 0 & 0 & 0 & 0 & 0 & 2 & 0 \\
\hline Pacific saury & Cololabis saira & 0 & 0 & 0 & 0 & 0 & 7 & 13 & 7 & 9 & 15 \\
\hline Sablefish & Anoplopoma fimbria & 0 & 0 & 0 & 8 & 0 & 18 & 4 & 0 & 0 & 9 \\
\hline Wolf eel & Anarrhichthys ocellatus & 5 & 0 & 48 & 0 & 7 & 4 & 10 & 5 & 8 & 0 \\
\hline Jack mackerel & Trachurus symetricus & 8 & 7 & 14 & 14 & 11 & 4 & 2 & 11 & 11 & 6 \\
\hline Chub mackerel & Scomber japonicus & 28 & 2 & 4 & 8 & 0 & 11 & 8 & 7 & 2 & 2 \\
\hline Starry flounder & Platichthys stellatus & 3 & 2 & 6 & 10 & 7 & 4 & 6 & 2 & 6 & 0 \\
\hline Pacific sanddab & Citharichthys sordidus & 13 & 2 & 8 & 0 & 0 & 4 & 2 & 5 & 2 & 4 \\
\hline Ocean sunfish & Mola mola & 0 & 2 & 0 & 4 & 0 & 11 & 4 & 18 & 0 & 4 \\
\hline \multicolumn{2}{|l|}{ Number of collections } & 40 & 42 & 50 & 50 & 28 & 28 & 48 & 44 & 53 & 47 \\
\hline
\end{tabular}

Fig. 6 and the percent occurrence of each cluster by cruise along with some mean environmental variables are given in Table 4 . Cluster group 1 occurred mainly inshore at low surface temperatures (Table 4). It was absent in June 2000 and occurred more frequently in September (44 occurrences) than June (14 occurrences). The strongest indicator species for cluster

Table 2. Total number of taxa, Pielou's evenness index, and Shannon-Weiner and Simpson's diversity indices for all nekton taxa collected during the 10 cruises in June and September of 1998 through 2002

\begin{tabular}{|ccccc|}
\hline Cruise & No. taxa & Evenness & Shannon & Simpson \\
\hline Jun 98 & 26 & 0.596 & 1.942 & 0.798 \\
Sep 98 & 24 & 0.226 & 0.720 & 0.268 \\
Jun 99 & 29 & 0.261 & 0.878 & 0.328 \\
Sep 99 & 31 & 0.436 & 1.498 & 0.697 \\
Jun 00 & 31 & 0.197 & 0.675 & 0.239 \\
Sep 00 & 39 & 0.333 & 1.221 & 0.505 \\
Jun 01 & 35 & 0.411 & 1.463 & 0.619 \\
Sep 01 & 30 & 0.434 & 1.476 & 0.608 \\
Jun 02 & 37 & 0.429 & 1.549 & 0.678 \\
Sep 02 & 36 & 0.686 & 2.460 & 0.879 \\
\hline
\end{tabular}

group 1 were subyearling Chinook salmon and Pacific herring, although both smelt species, American shad, Pacific hake, spiny dogfish, and starry flounder were also significant indicators of this group (Table 3). Cluster group 2 was a large, heterogeneous grouping with no significant indicator species and showed relatively little cohesion in its distribution pattern, since it occurred in all cruises and areas. Cluster group 3 was generally found inshore to mid-shelf, occurred much more during June than September, with the exception of 2001, and was represented most strongly by market squid (Table 3). It was associated with the lowest mean salinity (Table 4). Although it included species such as juvenile and adult coho salmon which may be associated with the plume at relatively high, but insignificant IVs, the species that were significant indicators are not generally known to be associated with the plume. Cluster group 4 was usually found from the middle to outer shelf, most frequently off Washington, and its indicator species were Pacific sardine and chub mackerel, species that migrate northward seasonally from off California. Cluster group 5 was found across much of the shelf, occurred most frequently off Washington, and had the northernmost mean latitude (Fig. 6, 

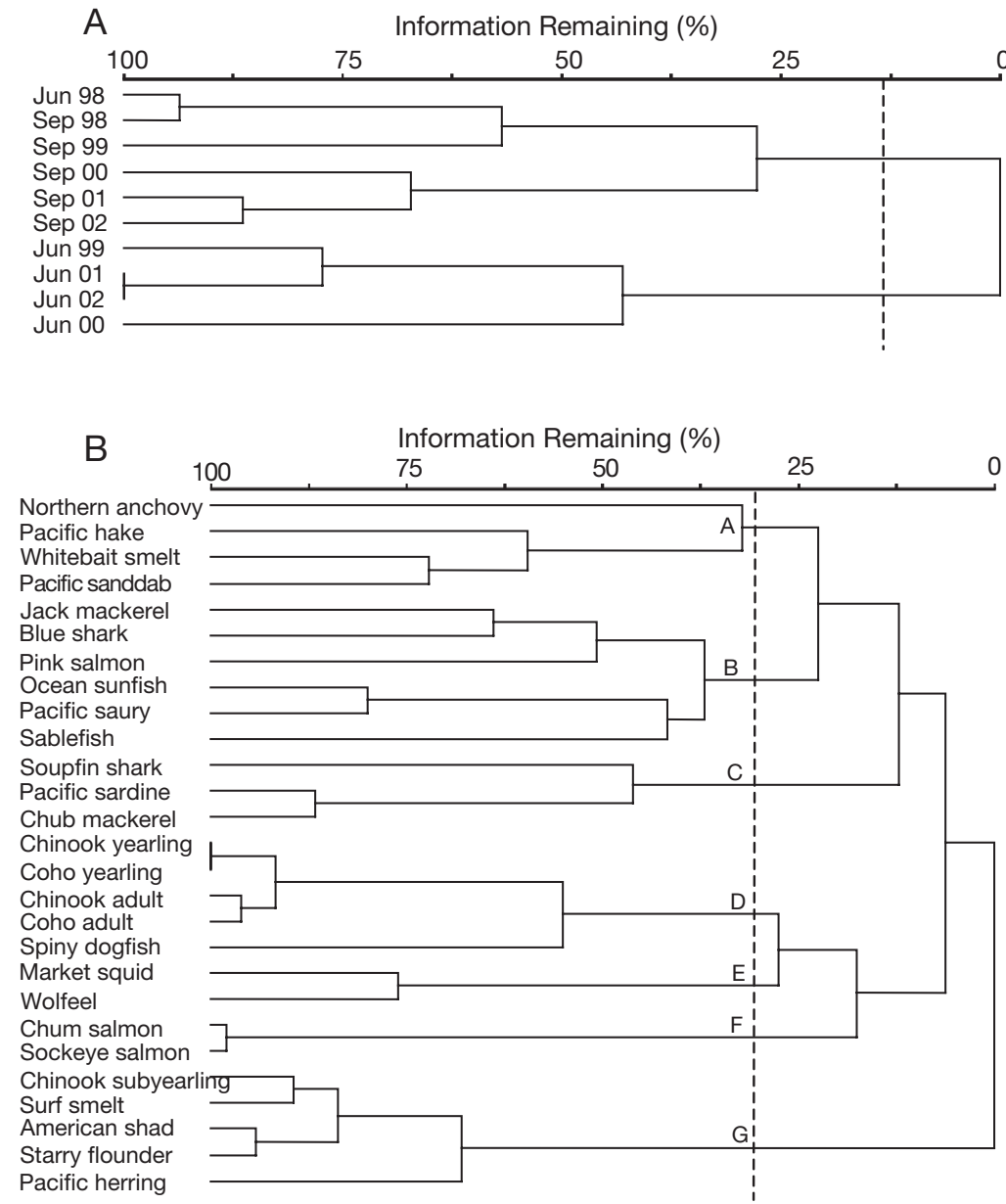

Fig. 5. (A) Results of cluster analysis using a 10 cruise by 27 non-rare species matrix (abundance data pooled by cruise) showing relationships among the individual cruises. (B) Cluster analysis showing relationships among the dominant species for all cruises combined. Dashed lines indicate the cutoff levels for each cluster group. Species groupings identified are labeled A-G. See Table 1 for scientific names

Table 4). Its strongest indicator species was yearling coho salmon, but juvenile chum, pink, and sockeye salmon were also significant indicators (Table 3). Cluster group 6 (Pacific saury, ocean sunfish, northern anchovy, and jack mackerel) was usually found farther offshore than other cluster groups, at the highest seasurface temperatures and salinities, and was generally found along all transects.

\section{Ordination analysis}

Joint-plots overlaid with the cluster groups are shown for 2 of the 3 axes from the NMS ordination of samples (Fig. 7A), and similarly for the species centroids (Fig. 7B). Environmental variables that explain at least $10 \%$ of the variance in the sample ordination scores $\left(r^{2} \geq 0.10\right)$ are shown as vectors. Although the stress (lack of fit) was high (22.51), stability was good (0.0001) and the results appeared to be quite interpretable ecologically. Variation in distances between samples in the 3dimensional ordination space explained about $55 \%$ of the variation in distances between samples in the original 27-dimensional species space. The proportion of the original variation explained by each of the ordination axes $\left(\mathrm{r}^{2}\right)$ was (1) $0.184,(2) 0.188$, (3) 0.179 (total $=0.552$ ).

Sample cluster groups occupied fairly distinct regions of the ordination, except for sample cluster group 2, which was broadly distributed over much of the space defined by the first 2 ordination axes (Fig. 7A). Not surprisingly, the centroids for the different species in the 2-dimensional ordinations space are found near the positions of the sample cluster groups for which they are indicators (compare Fig. 7 and Table 3). Positions of cluster groups and species centroids indicated an inshore distribution for cluster 1 and its indicator species, a northerly and broad cross-shelf distribution for group 5 and its indicator species, and an offshore distribution for group 6 and its indicator species (Fig. 7 and Table 3).

Species with the highest IVs (Pacific herring, Pacific sardines, market squid, and yearling coho salmon) showed strong separation in multivariate space (Fig. 8). Month and years did not separate well by NMS (not shown), suggesting some substantial overlap in species composition on a temporal basis, although sample cluster group 1, for which subyearling Chinook salmon was an important component, usually occurred more frequently in September than June (Table 4). Subyearling Chinook salmon leave their natal rivers and enter the ocean throughout the summer and usually are more abundant off Oregon and Washington in September than in June.

Moderately strong correlations with environmental variables occurred for all 3 axes, although those with Axis 1 were the strongest (Table 5). Axis 1 was negatively correlated with distance from shore, bottom depth, temperature and transparency and was positively correlated with chlorophyll and several macronutrients. This suggests that the first axis of the ordination reflected mainly differences in inshore/offshore distributions of the different species (Table 4). Axis 2 was positively correlated only with latitude, which would indicate a north/south effect. Axis 3 showed weaker negative associations with density, salinity, 
Table 3. Indicator values (IV) of species for the different sample cluster groups. (Number of hauls given in parentheses.) IV values indicate percent of perfect indication. Those listed in bold are significant at $p<0.05$

\begin{tabular}{|c|c|c|c|c|c|c|c|}
\hline \multirow[t]{2}{*}{ Species } & \multirow[t]{2}{*}{ Group } & \multicolumn{6}{|c|}{ Cluster } \\
\hline & & $1(57)$ & $2(96)$ & $3(46)$ & $4(37)$ & $5(107)$ & $6(44)$ \\
\hline Chinook subyearling & 1 & 55 & 2 & 4 & 2 & 2 & 0 \\
\hline Pacific herring & 1 & 61 & 1 & 3 & 3 & 0 & 0 \\
\hline Whitebait smelt & 1 & 25 & 0 & 0 & 0 & 0 & 0 \\
\hline Surf smelt & 1 & 16 & 0 & 2 & 0 & 0 & 0 \\
\hline Northern anchovy & 1 & 11 & 7 & 3 & 6 & 0 & 0 \\
\hline American shad & 1 & 8 & 0 & 0 & 3 & 0 & 0 \\
\hline Pacific hake & 1 & 9 & 3 & 0 & 0 & 0 & 0 \\
\hline Spiny dogfish & 1 & 9 & 0 & 1 & 1 & 6 & 0 \\
\hline Starry flounder & 1 & 7 & 1 & 1 & 0 & 1 & 0 \\
\hline Chinook yearling & & 13 & 6 & 11 & 4 & 11 & 0 \\
\hline Pacific sanddab & & 2 & 3 & 1 & 0 & 0 & 0 \\
\hline Market squid & 3 & 2 & 1 & 86 & 0 & 1 & 0 \\
\hline Wolf eel & 3 & 0 & 5 & 8 & 0 & 2 & 0 \\
\hline Soupfin shark & 3 & 0 & 0 & 5 & 2 & 1 & 0 \\
\hline Coho adult & & 4 & 4 & 10 & 3 & 9 & 0 \\
\hline Pacific sardine & 4 & 0 & 1 & 0 & 82 & 1 & 1 \\
\hline Chub mackerel & 4 & 0 & 1 & 0 & 26 & 0 & 1 \\
\hline Coho yearling & 5 & 2 & 1 & 12 & 6 & 51 & 1 \\
\hline Chum juvenile & 5 & 0 & 0 & 6 & 1 & 15 & 0 \\
\hline Pink juvenile & 5 & 0 & 0 & 0 & 0 & 7 & 0 \\
\hline Sockeye juvenile & 5 & 0 & 1 & 0 & 0 & 8 & 0 \\
\hline Chinook adult & & 8 & 3 & 7 & 3 & 8 & 0 \\
\hline Pacific saury & 6 & 1 & 0 & 0 & 0 & 0 & 25 \\
\hline Jack mackerel & 6 & 0 & 0 & 0 & 1 & 1 & 24 \\
\hline Ocean sunfish & 6 & 0 & 0 & 0 & 0 & 0 & 19 \\
\hline Blue shark & 6 & 0 & 0 & 2 & 0 & 1 & 14 \\
\hline Sablefish & & 0 & 0 & 0 & 3 & 0 & 4 \\
\hline
\end{tabular}

marine protected areas (Piet \& Rijnsdorp 1998, Mouillot et al. 2002). For our study, we used similar metrics to examine the effects of strong interannual physical forcing on pelagic nekton communities. The pelagic zone in this ecosystem is not heavily fished, and thus changes in community structure can be attributable primarily to environmental changes.

\section{Abundance and distribution in relation to environment}

Our 5 yr study period was remarkable in terms of its environmental variability. The first year of our sampling occurred during a strong El Niño, comparable in magnitude to the 1982/1983 event that, up to that time, had been the strongest ever recorded (Chavez et al. 2002). Oceanographic signatures of unusual conditions off Oregon were first noted in August 1997 as a rise in sea level (Strub \& James 2002). This was followed by an increase in water temperatures and anomalously strong poleward flows by September 1997 (Kosro 2002). The unusually warm subsurface water persisted until the sum-

phosphate, and positive relations with stability. Correlations with salinity, density, and stability on the third axis suggest some association with highly stratified fresh water such as the Columbia River plume. The strongest species correlations with Axis 1 (inshore/offshore) were subyearling Chinook salmon (0.51), yearling Chinook salmon (0.37), and blue shark (-0.34); with Axis 2 (north/south) were yearling coho salmon (0.48) and northern anchovy (-0.31); and with Axis 3 (plume waters) were market squid $(0.42)$ and yearling coho salmon (0.33).

\section{DISCUSSION}

With the growing interest in managing entire marine ecosystems rather than individual fish stocks and in determining essential fish habitat (e.g. Botsford et al. 1997, Rosenberg et al. 2000, Browman \& Stergiou 2004, Pikitch et al. 2004), there has been a substantial increase in studies examining aggregate community metrics. Many of these studies are aimed at evaluating fisheries impacts (Bianchi et al. 2000, Rice 2000, Nicholson \& Jennings 2004) or assessing the efficacy of mer of 1998 (Huyer et al. 2002). The biological signals associated with the unusual northward transport and warm water anomalies were also evident but somewhat delayed. Keister et al. (2005) found unusual zooplankton species of southern or offshore origins, including euphausiids, copepods, and chaetognaths, that began to show up off Oregon in December 1997 and persisted in the plankton until fall 1998. Peterson \& Keister (2002) also found warm-water copepod species persisting through fall of 1998. Similarly, Pearcy (2002) identified unusual occurrences or anomalous abundance levels of nekton species in Oregon waters, starting mainly in fall of 1997, and continuing until fall of 1998. Thus, the June 1998, and to a lesser extent, the September 1998 cruises were most likely impacted by this event. Although June 1998 was not unusual in terms of upwelling or measured sea-surface temperatures, it had the highest frequency of occurrence of Pacific hake, chub mackerel, whitebait smelt, Pacific sardine, and Pacific sanddab of all our cruises (Table 1).

In contrast, a major La Niña began in 1999 that may have coincided with a regime change manifested throughout the North Pacific Ocean, bringing with it anomalously cold water (Peterson \& Schwing 2003). 

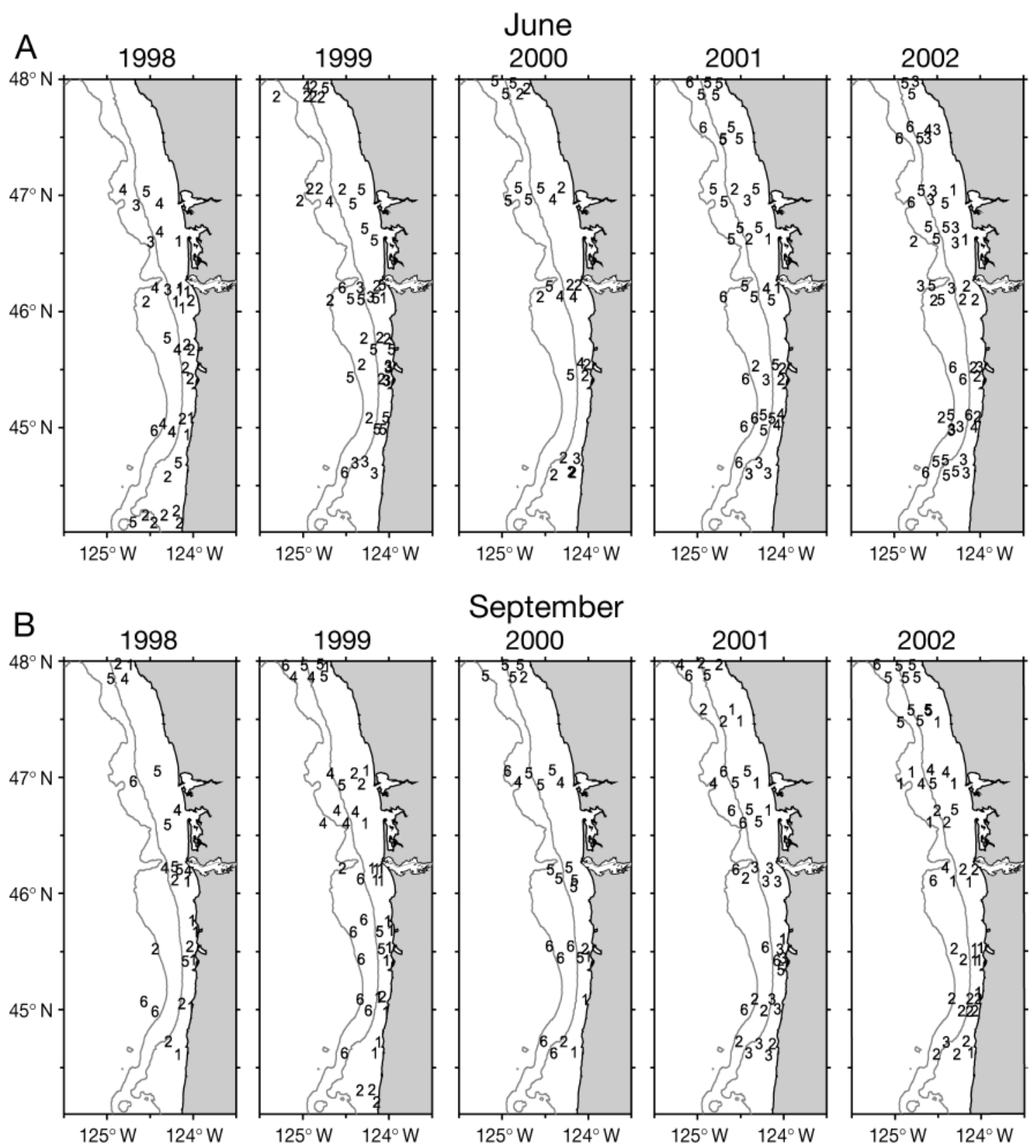

Fig. 6. Geographic location of cluster sample groups during the (A) June and (B) September cruises. See Table 3 for the dominant species representing each cluster group. To improve legibility, station groups are plotted $\pm 0.05^{\circ}$ latitude from their actual location; longitude not changed. The 100 and $200 \mathrm{~m}$ depth contours are also shown

Upwelling off California during the spring and summer of 1999 exceeded all previous years on record (Schwing et al. 2000), but upwelling off Oregon and Washington was not much different in 1999 than in the other years of our study except during September (Fig. 2). Although average nutrient concentration off Oregon was higher during summer 1999 than during summer 1998, average chlorophyll concentration and copepod biomass was not much higher in 1999 than in 1998. However, there was a dramatic change in cope- pod species composition off Oregon and elsewhere in the Northeast Pacific between these 2 yr (Peterson et al. 2002). In terms of nekton, 1999 was the start of a dramatic increase in the abundance of forage fishes, particularly Pacific herring and Pacific sardines, and a decrease in large migratory predatory fishes, which may be linked to changes in ocean conditions (Emmett \& Brodeur 2000, Brodeur et al. 2003a).

During June 2000 the pattern of sea-surface temperature off Oregon and Washington was fairly similar to 
Table 4. (A) Percent occurence of each sample cluster group within each cruise with (B) means (SD) of selected environmental or station variables associated with those cluster groups. For number of hauls see Table 3

\begin{tabular}{|lcccccc|}
\hline (A) Cluster group: & 1 & 2 & 3 & 4 & 5 & 6 \\
\hline Jun 1998 & 22.2 & 36.1 & 8.3 & 19.4 & 11.1 & 2.8 \\
Sep 1998 & 26.9 & 23.1 & 0.0 & 15.4 & 23.1 & 11.5 \\
Jun 1999 & 2.2 & 37.0 & 19.6 & 4.3 & 32.6 & 4.3 \\
Sep 1999 & 36.4 & 15.9 & 0.0 & 15.9 & 13.6 & 18.2 \\
Jun 2000 & 0.0 & 46.2 & 3.8 & 15.4 & 34.6 & 0.0 \\
Sep 2000 & 11.1 & 11.1 & 0.0 & 7.4 & 48.1 & 22.2 \\
Jun 2001 & 4.5 & 11.4 & 13.6 & 6.8 & 47.7 & 15.9 \\
Sep 2001 & 12.2 & 22.0 & 26.8 & 4.9 & 14.6 & 19.5 \\
Jun 2002 & 4.0 & 18.0 & 30.0 & 4.0 & 30.0 & 14.0 \\
Sep 2002 & 27.7 & 31.9 & 2.1 & 8.5 & 25.5 & 4.3 \\
& & & & & & \\
$(B)$ Variable & & & & & & \\
Distance offshore & 5.7 & 10.6 & 9.7 & 13.9 & 12.2 & 18.9 \\
$(\mathrm{n}$ miles) & $(5.8)$ & $(8.1)$ & $(6.3)$ & $(7.6)$ & $(6.5)$ & $(5.8)$ \\
Depth at station & 49 & 106 & 88 & 101 & 89 & 192 \\
$(\mathrm{~m})$ & $(29)$ & $(102)$ & $(81)$ & $(50)$ & $(41)$ & $(116)$ \\
Surface temperature & 11.8 & 12.5 & 13.4 & 13.2 & 13.5 & 13.7 \\
$\left({ }^{\circ} \mathrm{C}\right)$ & $(1.8)$ & $(2.0)$ & $(1.3)$ & $(0.8)$ & $(1.4)$ & $(1.4)$ \\
Latitude & 46.02 & 45.83 & 45.67 & 46.58 & 46.68 & 45.92 \\
$\left({ }^{\circ} \mathrm{N}\right)$ & $(0.86)$ & $(1.11)$ & $(0.95)$ & $(0.86)$ & $(1.02)$ & $(1.06)$ \\
Surface salinity & 31.3 & 30.6 & 29.9 & 31.2 & 30.3 & 31.5 \\
$($ psu) & $(2.5)$ & $(3.4)$ & $(3.3)$ & $(1.7)$ & $(3.1)$ & $(1.2)$ \\
\hline
\end{tabular}

2000 compared to other years. The Columbia River plume was also moderately developed during both months in 2000. Surface chlorophyll concentrations based on satellite measurements (Thomas et al. 2003) and our own unpublished measurements taken at $3 \mathrm{~m}$ were intermediate in 2000 compared to the previous and following years. In June 2000, our catches were dominated by one species, northern anchovy. This pattern of abundance contrasted with those of all other cruises (Fig. 4) and resulted in the lowest diversity and evenness values of our entire study. By September 2000, northern anchovy was rarely caught in our trawls and was replaced by Pacific herring and Pacific sardines.

Drought conditions prevailed in the spring/summer of 2001, causing the Columbia River plume to be effectively absent during the June cruise, although it was present in September (Fig. 3). Upwelling occurred primarily in July 2001, but did not lead to very high chlorophyll concentrations off

that in June 1998 and June 2001 (i.e. cooler temperatures onshore and warmer temperatures offshore). However, surface temperatures off northern Oregon and Washington were unusually warm in September
Newport, Oregon (Wheeler et al. 2003). Squid abundance increased markedly that year, and was especially high during the September cruise when it dominated our catches (Fig. 3). However, given that salinity
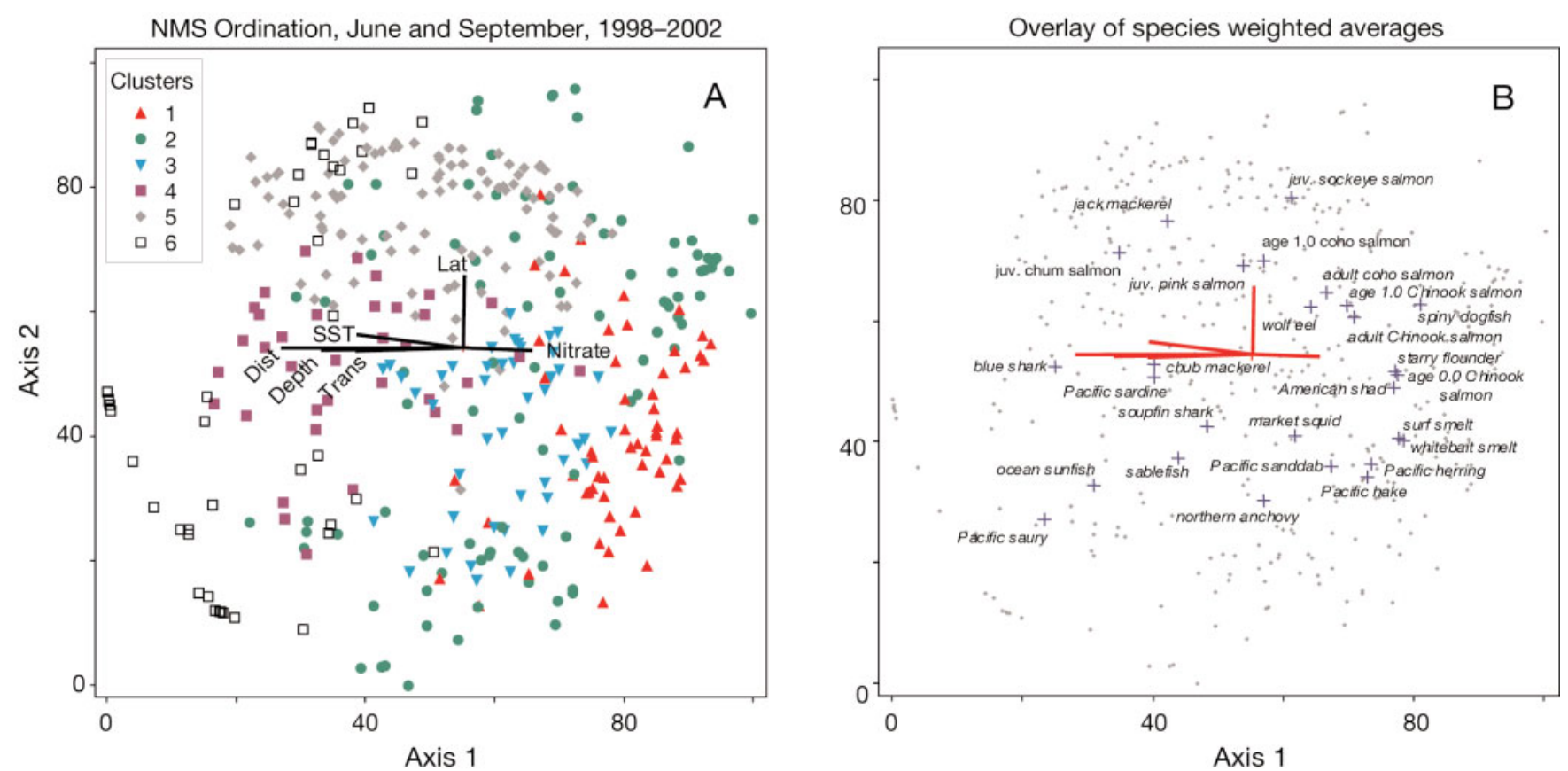

Fig. 7. Multidimensional Scaling (NMS) plots of 2 axes for all cruises combined showing distribution of (A) cluster groups and (B) species. Environmental variables with $\mathrm{r}^{2}>0.10$ are shown as vectors and are labeled in (A). Small gray dots in (B) show the sample scores for comparison. See Table 1 for scientific names 

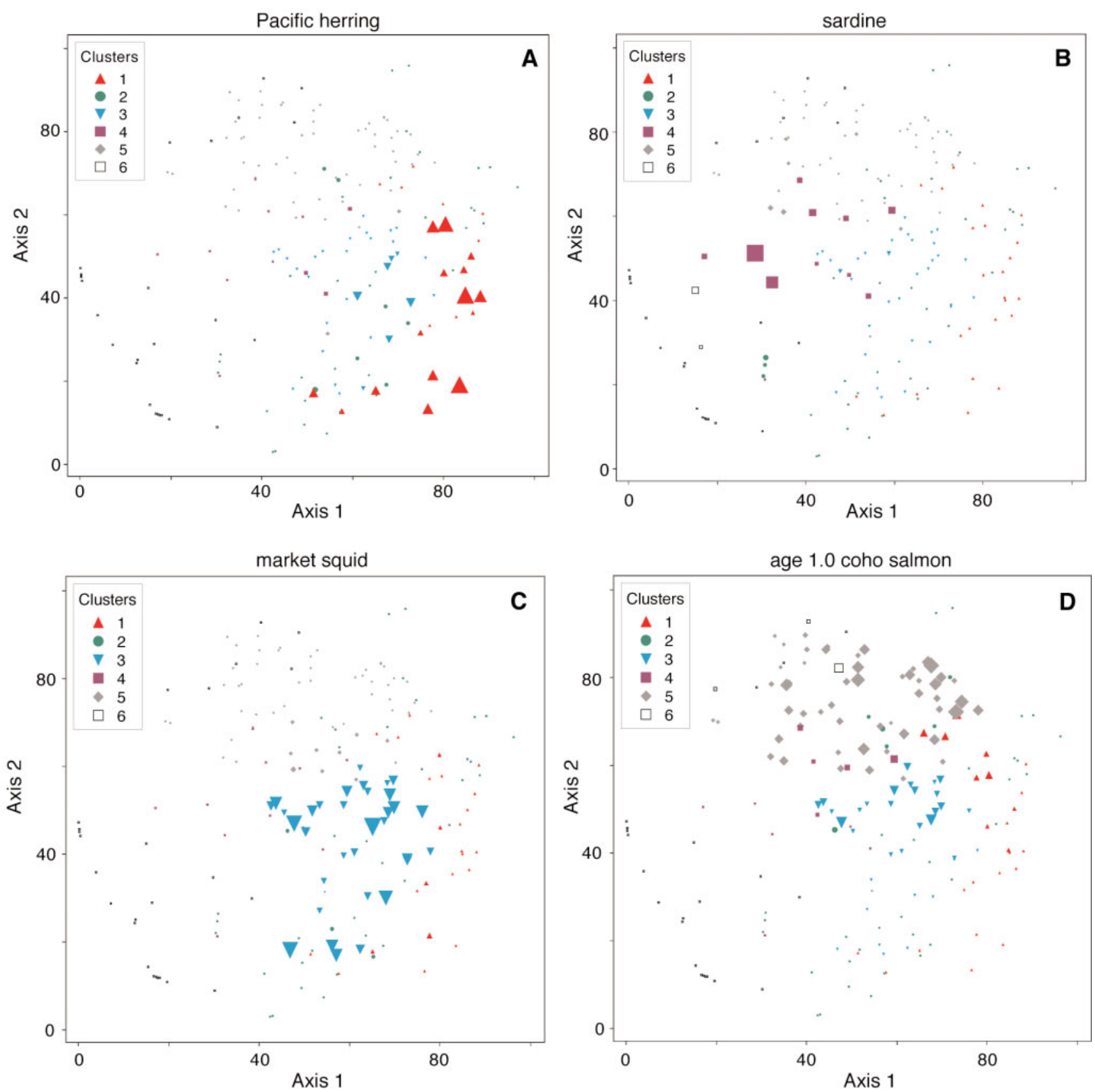

Fig. 8. Multidimensional Scaling (NMS) bubble plots of 4 dominant indicator species coded by cluster group. Shown are plots for (A) Pacific herring, (B) Pacific sardines, (C) market squid, and (D) yearling coho salmon. Size of the points is proportional to the catch of each species

was not strongly correlated with any of the NMS axes, and that none of the cluster groups appeared to be associated with the plume, the low runoff did not appear to affect nekton distributions to any major degree.

During summer 2002, a major shift in North Pacific currents led to an intrusion of cold, nutrient-laden subarctic water to the coast off Oregon. This intrusion triggered an anomalously large and intense phytoplankton bloom and subsequent near-bottom hypoxia that had im- portant ramifications for the ecosystem (Thomas et al. 2003, Wheeler et al. 2003, Grantham et al. 2004). Although the initial phase of this cold-water anomaly may have been present during our June cruise, the primary impact occurred during late summer and almost certainly affected the plankton and nekton in late summer and early fall. Although species diversity was very high during the September cruise, overall nekton abundance was the lowest of our sampling (Fig. 4). Many rare 
Table 5. Pearson Correlations (r) between ordination axes and environmental variables for the combined cruises. Sample size is 387 for all variables down to and including chlorophyll, 357 for the nutrient variables, and 269 for transparency. Significant correlations $(\mathrm{p}<0.01)$ are in bold

\begin{tabular}{|lrrr|}
\hline Variables & Axis 1 & Axis 2 & Axis 3 \\
\hline Distance from shore (n miles) & $\mathbf{- 0 . 5 2}$ & -0.01 & -0.06 \\
Bottom depth $(\mathrm{m})$ & $\mathbf{- 0 . 4 6}$ & -0.06 & -0.04 \\
Temperature $\left({ }^{\circ} \mathrm{C}\right)$ & $\mathbf{0 . 4 0}$ & 0.14 & 0.19 \\
Latitude $\left({ }^{\circ} \mathrm{N}\right)$ & 0.04 & $\mathbf{0 . 3 3}$ & -0.01 \\
Salinity $(\mathrm{psu})$ & -0.01 & -0.12 & $\mathbf{- 0 . 2 1}$ \\
Density $\left(\sigma_{\mathrm{T}}\right)$ & 0.05 & -0.13 & $\mathbf{- 0 . 2 2}$ \\
Stability $($ density $(20 \mathrm{~m})-$ & 0.07 & 0.12 & $\mathbf{0 . 2 0}$ \\
density $(1 \mathrm{~m}) / 19 \mathrm{~m})$ & & & \\
Chlorophyll $\left(\mu \mathrm{l}^{-1}\right)$ & $\mathbf{0 . 2 9}$ & 0.06 & -0.14 \\
Phosphate $(\mu \mathrm{M})$ & $\mathbf{0 . 2 5}$ & -0.10 & $\mathbf{- 0 . 2 1}$ \\
Nitrate $(\mu \mathrm{M})$ & $\mathbf{0 . 3 2}$ & -0.06 & -0.16 \\
Nitrite $(\mu \mathrm{M})$ & 0.15 & -0.05 & -0.06 \\
Ammonia $(\mu \mathrm{M})$ & 0.05 & 0.04 & 0.01 \\
Silicate $(\mu \mathrm{M})$ & $\mathbf{0 . 2 4}$ & -0.01 & -0.05 \\
Transparency & $\mathbf{0 . 4 0}$ & -0.07 & -0.05 \\
$\quad$ Secchi depth in m) & & & \\
\hline
\end{tabular}

species occurred only during this cruise (e.g. rock sole Lepidopsetta bilineata, butterfish Peprilus similis, and king-of-the-salmon Trachipterus altivelis). However, many of the common schooling pelagic forage fishes such as Pacific herring, Pacific sardine, smelts, and northern anchovy were absent or in low abundance.

\section{Nekton habitat and community structure}

Our community analyses suggested that there are groups of species that occur in similar water types, and these types are present in summer and fall during most years, although notable exceptions occurred. Seasonal shifts occur as migratory species enter the area from the south (Pacific hake, Pacific sardines, jack and chub mackerels), from offshore (Pacific saury and sharks), or from freshwater habitats (juvenile coho and Chinook salmon) that may dramatically alter the pelagic nekton species mix over the course of a summer. In a similar fashion, interannual differences in the strength of the California Current may affect the occurrence patterns of fish that inhabit more northern or southern latitudes (Brodeur et al. 2003a). Temperature appears to be an important variable regulating habitat suitability for species such as Pacific sardines (Emmett et al. in press) as much of the newly upwelled water in this region is below their thermal preferendum. Conversely, juvenile salmon are often restricted to the nearshore habitats where the temperatures are appreciably cooler (Brodeur et al. 2004).

The strongest gradients in sea-surface temperature usually occur across the shelf in this region (Fig. 3). The width of the upwelling band of cold temperatures and generally high productivity varies from year to year and seasonally. Comparing our results with other studies of the community structure of plankton and nekton, we conclude that in this upwelling region, inshore/offshore gradients tend to dominate over north/south gradients. Based on 3 yr of zooplankton sampling off Oregon, Morgan et al. (2003) found significant differences between inshore and offshore copepod communities during each year. Similar patterns were observed for neuston and total water column zooplankton communities off southern Oregon and northern California (Peterson \& Keister 2002, Reese et al. 2005). In addition, ichthyoplankton communities show strong inshore/offshore structure that may reflect the habitats of the spawning adults (Doyle et al. 2002 and references therein).

The situation for pelagic nekton is not as clear. In an analysis of purse seine collections off Oregon and Washington in 1985, Brodeur et al. (2003b), observed different results using 2 different classification techniques, a cluster analysis, similar to that used in this paper, and Two-way Indicator Species Analysis or TWINSPAN. Sample groups based on the TWINSPAN analysis indicated pronounced inshore/offshore patterns, whereas those based on cluster analysis produced more north/south groupings. Latitude $(\mathrm{r}=-0.65)$ and longitude $(\mathrm{r}=0.36)$ were most highly correlated with Detrended Correspondence Analysis (DCA) ordination axes 1 and 2, respectively (Brodeur et al. 2003b). In sampling similar to the present study but in southern Oregon and northern California, Brodeur et al. (2004) found both inshore/offshore and north/south groupings, the latter affected by strong differences in topography and a coastal cape that affected shelf circulation. Depth/temperature and salinity in this more southern region were strongly correlated with ordination axes.

Although there is some indication that the Columbia River plume may affect the distributions of some species of nekton, the results are equivocal overall. Although surface temperature and chlorophyll are generally higher in the plume than in adjacent upwelled waters, they are not a strong indicator of plume waters. In addition to salinity, the best signatures of plume waters are macronutrients such as silicate and nitrate (Hill \& Wheeler 2002, Morgan et al. in press), but since the nutrients are affected by biological activity and can be taken up by the biota with increased ocean residence time, they are not useful measures of the plume as it spreads along the coast.

Our approach in this paper was to analyze all samples from all cruises together in a single multivariate analysis. Hence, a particular cluster group would be consistent in its membership among the different cruises, and the occurrence and distribution of different cluster 
groups could be examined in relation to environmental conditions during each cruise. A drawback to this approach was the substantial variability in catches between years and months, which led to high multivariate stress (lack of fit) levels. We initially tried other ways of grouping the data by individual cruises (10 different analyses) and grouping by month (2 different analyses). The amount of variance explained was greater (range 0.669 to 0.806 ) and the stress was smaller (13.48 to 16.88) for analyses of individual cruises than for the analyses of data pooled across the years $(0.560$ to 0.605 and 21.43 to 21.50 , respectively). We also tried a data transformation called Beals smoothing, which reduces the noise and enhances the dominant trends (McCune \& Grace, 2002). For NMS on the entire data set (387 samples by 27 species), Beals smoothing greatly decreased the stress (10.73) and increased the variance explained (93.6\%). However, almost all of the variance (>86\%) was explained by the first axis, which was highly correlated with distance offshore and temperature. Since Beals smoothing tends to highlight 'habitat favorability' for the different species, it can distort or mask temporal changes in community structure caused, for example, by fish migration (e.g. the entry of juvenile salmon into the ocean or their migrations in the ocean). Thus, we concluded that NMS of the pooled data without Beals smoothing was the most reasonable and ecologically interpretable method despite the inherently high variability.

\section{Implications for continued studies and management}

The pelagic environment off Oregon is extremely dynamic, and faster-swimming nekton are probably able to compensate for prevailing currents and remain in their preferred habitats. The exception may be young juvenile salmon, which are relatively weak swimmers and may have to traverse unfavorable nearshore habitats once they leave their natal streams to get to regions of optimal marine conditions (Brodeur et al. 2004). The relationships between the distributions of our species groups and environmental variables suggest nekton have habitat preferences. However, nekton species may actually have been responding to other biotic variables (type and quantity of prey available) that were not included in our analyses, but that may be correlated to some degree with the variables we used. Future examination of the relationship between these nekton and their food resources is clearly warranted. Moreover, we used surface measurements in many cases, although the nekton caught could have been anywhere in the top $20 \mathrm{~m}$ of the water column. While we assumed that our surface trawls are representative of the nekton community, we under- stand that some species occupy deeper layers during the day and only come up to the upper $15 \mathrm{~m}$ at night (Emmett et al. 2004). Also, large, fast-swimming nekton such as albacore tuna Thunnus alalunga are abundant in our sampling region during the warmer time periods but are able to avoid capture in our trawls.

An important corollary to these findings is that the preferred habitat of pelagic nekton species off Oregon and Washington appears to expand and contract in relation to the dynamic nature of the California Current and is driven by changing ocean conditions at both seasonal and interannual periodicities. For example, the proportional occurrence of sample cluster group 1, dominated by subyearling Chinook salmon and Pacific herring, varied from a low of 11 and $12.2 \%$ in September 2000 and 2001, respectively, to a high of $36 \%$ in September 1999. Contrastingly, the proportional occurrence for sample cluster group 3, dominated by market squid, varied from a high of $27 \%$ in September 2001 to a low of $0 \%$ in the same month during 1998, 1999, and 2000. For each pelagic cluster group identified, significant variation in occurrence occurred between seasons and years, implying that their preferred habitat expands and contracts under differing environmental conditions.

The distribution of different pelagic fish groupings in 3-dimensional quantitative space is explained largely by north/south and onshore/offshore gradients. Although these metrics are not in themselves dynamic, they likely embody habitat features for each pelagic group that responded to the changing environmental conditions encountered in the California Current during 1998 to 2002. Pelagic nekton species that respond to onshore/offshore or latitudinal gradients are likely responding to habitat characteristics that expand or contract on seasonal and interannual time frames. Although sea-surface temperature, density, and salinity are physical variables that are included as meaningful determinants of habitat for pelagic species in the California Current, it is likely that other unmeasured physical and biological metrics are represented in the cross- and along-shelf gradients. The suite of physical and biological metrics that define habitat features for pelagic species could be better described by devising a combined metric of 'ocean conditions' that captures the availability of suitable habitat for pelagic species.

Our study has provided a more complete understanding of the habitats occupied by coastal pelagic fishes and may assist with management of these species. We have shown that many pelagic nekton overlap substantially in space and time, and this information will be useful in elucidating ecological (competition and predation) and fishery (potential by-catch) interactions in this ecosystem and implementation of ecosystem-based management practices. 
Acknowledgements: We thank the captains and crew of the fishing and research vessels for their cooperation and assistance in the sampling. We acknowledge the assistance of the many NOAA Fisheries and OSU scientists in collecting and processing the data and in providing logistic support, including C. Bucher, S. Hinton, K. Jacobson, W. Peterson, T. Sandell, and R. Schabetsberger. We thank J. Keister, D. Reese, S. Pool, W. Pearcy, and an anonymous reviewer for critical reviews of the manuscript. Funding was provided by the Bonneville Power Administration and the Northeast Pacific GLOBEC Program and is contribution number 244 of the U.S. GLOBEC Program.

\section{LITERATURE CITED}

Bianchi G, Gislason H, Graham L, Hill L and 7 others (2000) Impact of fishing on size composition and diversity of demersal fish communities. ICES J Mar Sci 57:558-571

Botsford LW, Castilla JC, Peterson CH (1997) The management of fisheries and marine ecosystems. Science 277:509-515

Brodeur RD, Pearcy WG (1986) Distribution and relative abundance of pelagic non-salmonid nekton off Oregon and Washington, 1979-1984. NOAA Tech Rep NMFS 46: 1-85

Brodeur RD, Pearcy WG (1992) Effects of environmental variability on trophic interactions and food web structure in a pelagic upwelling ecosystem. Mar Ecol Prog Ser 84: 101-119

Brodeur RD, Frost B, Hare SR, Francis RC, Ingraham WJ Jr (1996) Interannual variations in zooplankton biomass in the Gulf of Alaska and covariations with California Current zooplankton biomass. Calif Coop Ocean Fish Investig Rep 37:81-99

Brodeur RD, Pearcy, WG, Ralston, S (2003a) Abundance and distribution patterns of nekton and micronekton in the Northern California Current Transition Zone. J Oceanogr 59:415-434

Brodeur RD, Fisher JP, Ueno Y, Nagasawa K, Pearcy WG (2003b) An east-west comparison of the Transition Zone coastal epipelagic nekton of the North Pacific Ocean. J Oceanogr 59:515-535

Brodeur RD, Fisher, JP, Teel D, Emmett RL, Casillas E, Miller TW (2004) Distribution, growth, condition, origin and environmental and species associations of juvenile salmonids in the Northern California Current. Fish Bull US 102:25-46

Browman HI, Stergiou KI (2004) Perspectives on ecosystembased approaches to the management of marine resources. Mar Ecol Prog Ser 274:269-303

Chavez FP, Collins CA, Huyer A, Mackas DL (eds) (2002) Observations of the 1997-1998 El Niño along the West Coast of North America. Prog Oceanogr 54:1-511

Chavez FP, Ryan J, Lluch-Cota SE, Ňiquen M (2003) From anchovies to sardines and back: multidecadal change in the Pacific Ocean. Science 299:217-221

Clarke KR, Warwick RM (2001) Change in marine communities: an approach to statistical analysis and interpretation 2nd edn. PRIMER-E Ltd, Plymouth

Doyle MJ, Mier KL, Busby MS, Brodeur, RD (2002) Regional variations in springtime ichthyoplankton assemblages in the Northeast Pacific Ocean. Prog Oceanogr 53:247-281

Dufrene M, Legendre P (1997) Species assemblages and indicator species: the need for a flexible asymmetrical approach. Ecol Monogr 67(3):345-366

Emmett RL, Brodeur RD (2000) The relationship between recent changes in the pelagic nekton community off Ore- gon and Washington and physical oceanographic conditions. Bull North Pac Anadr Fish Comm 2:11-20

Emmett RL, Brodeur RD, Orton P (2004) The vertical distribution of juvenile salmon and associated fishes in the Columbia River Plume. Fish Oceanogr 13(5):392-402

Emmett RL, Brodeur RD, Miller TW, Pool SS, Bentley PJ, Krutzikowsky GK, McCrae J (in press) Pacific sardine (Sardinops sagax) abundance, distribution and ecological relationships in the Pacific Northwest. Calif Coop Ocean Fish Investig Rep

Field JG, Clarke KR, Warwick RM (1982) A practical strategy for analyzing multispecies distribution patterns. Mar Ecol Prog Ser 8:3752

Freeland HJ, Gatien G, Huyer A, Smith RL (2003) Cold halocline in the northern California Current: an invasion of subarctic water. Geophys Res Lett 30(3), 1141, doi: 10.1029/2002GL016663

Grantham BA, Chan F, Nielsen KJ, Fox DS, Barth JA, Huyer J, Lubchenco J, Menge BA (2004) Upwelling-driven nearshore hypoxia signals ecosystem and oceanographic changes in the northeast Pacific. Nature 429:749-754

Hickey BM (1998) Coastal oceanography of western North America from the tip of Baja California to Vancouver Island (coastal segment 8E). In: Robinson AR, Brink $\mathrm{KH}$ (eds) The sea, ideas and observations on progress in the study of the seas, Vol 11. The global coastal ocean: regional studies and syntheses. Interscience Publishers, New York, p 345-393

Hickey BM, Banas NS (2003) Oceanography of the U.S. Pacific Northwest coastal ocean and estuaries with application to coastal ecology. Estuaries 26(4B):1010-1031

Hill JK, Wheeler PA (2002) Organic carbon and nitrogen in the northern California current system: comparison of offshore, river plume, and coastally upwelled waters. Prog Oceanogr 53:369-387

Huyer A, Smith RL, Fleischbein J (2002) The coastal ocean off Oregon and Northern California during the 1997-8 El Niño. Prog Oceanogr 54:311-341

Keister JE, Johnson TB, Morgan CA, Peterson WT (2005) Biological indicators of the timing and direction of the warmwater advection during the 1997/98 El Niño off the central Oregon coast, USA. Mar Ecol Prog Ser 295:43-48

Kosro PM (2002) A poleward jet and an equatorward undercurrent observed off Oregon and northern California during the 1997-98 El Niño. Prog Oceanogr 54:343-360

Kruskal JB (1964) Nonmetric multidimensional scaling: a numerical method. Psychometrika 29:127

Krutzikowsky GK, Emmett RL (2005) Diel differences in surface trawl fish catches off Oregon and Washington. Fish Res 71:365 - 371

Logerwell EA, Mantua N, Lawson PW, Francis RC, Agostini VN (2003) Tracking environmental processes in the coastal zone for understanding and predicting Oregon coho (Oncorhynchus kisutch) marine survival. Fish Oceanogr 12:554-568

Magurran, AE (1988) Ecological diversity and its measurement. Princeton University Press, Princeton, NJ

Mantua NJ, Hare SR, Zhang Y, Wallace JM, Francis RC (1997) A Pacific interdecadal climate oscillation with impacts on salmon production. Bull Am Meteorol Soc 78: 1069-1079

McCune B, Mefford MJ (1999) Multivariate analysis of ecological data, version 4.36 beta. MjM Software, Gleneden Beach, OR

McCune B, Grace JB (2002) Analysis of ecological communities. MjM Software, Gleneden Beach, OR

McGowan JA, Cayan DR, Dorman LM (1998) Climate-ocean 
variability and ecosystem response in the Northeast Pacific. Science 281:210-217

Miller AJ, Chai F, Chiba S, Moisan JR, Neilson DJ (2004) Decadal-scale climate and ecosystem interactions in the North Pacific Ocean. J Oceanogr 60:163-188

Morgan CA, Peterson WT, Emmett RL (2003) Onshore-offshore variations in copepod community structure off the Oregon coast during the summer upwelling season. Mar Ecol Prog Ser 249:223-236

Morgan CA, DeRobertis A, Zabel RW (in press) Columbia River plume fronts: I. Hydrography, zooplankton distribution, and community composition. Mar Ecol Prog Ser

Mouillot D, Culioli JM, Chi TD (2002) Indicator species analysis as a test of non-random distribution of species in the context of marine protected areas. Environ Cons 29:385-390

Nicholson MD, Jennings S (2004) Testing candidate indicators to support ecosystem-based management: the power of monitoring surveys to detect temporal trends in fish community metrics. ICES J Mar Sci 61:35-42

Pearcy WG (2002) Marine nekton off Oregon and the 1997-98 El Niño. Progr Oceanogr 54: 399-403

Pearcy WG, Schoener A (1987) Changes in the marine biota coincident with the 1982-1983 El Niño in the northeastern subarctic Pacific Ocean. J Geophys Res 92 No. C13, 14417-14428

Pearcy W, Fisher J, Brodeur R, Johnson S (1985) Effects of the 1983 El Niño on coastal nekton off Oregon and Washington. In: Wooster WS (ed) El Niño North: Niño effects in the Eastern Subarctic Pacific Ocean, WSG-WO 85-3. Washington Sea Grant Program, Seattle, WA, p 188-204

Peterson WT, Keister JE (2002) The effect of a large cape on distribution patterns of coastal and oceanic copepods off Oregon and northern California during the 1998-1999 El Niño- La Niña. Progr Oceanogr 53:389-411

Peterson WT, Schwing FB (2003) A new climate regime in northeast Pacific ecosystems. Geophys Res Lett 30(17), 1896, doi: 10.1029/2003GL017528

Peterson WT, Keister JE, Feinberg L (2002) The effects of the 1997-1999 El Niño/La Niña events on hydrography and

Editorial responsibility: Kenneth Sherman (Contributing Editor), Narragansett, Rhode Island, USA zooplankton off the central Oregon coast. Progr Oceanogr 54(1-4):381-398

Piet G, Rijnsdorp AD (1998) Changes in the demersal fish assemblage in the south-eastern North Sea following the establishment of a protected area ('plaice box'). ICES J Mar Sci 55:420-429

Pikitch EK, Santora C, Babcock EA, Bakun A and 13 others (2004) Ecosystem-based fishery management. Science 305:346-347

Reese DC, Miller TW, Brodeur RD (2005) Community structure of near-surface zooplankton in the northern California Current in relation to oceanographic conditions. DeepSea Res II 52:29-50

Rice JC (2000) Evaluating fishery impacts using metrics of community structure. ICES J Mar Sci 57:682-688

Rosenberg A, Bigford TE, Leathery S, Hill RL, Bickers K (2000) Ecosystem approaches to fishery management through essential fish habitat. Bull Mar Sci 66:535-542

Scheuerell MD, Williams JG (2005) Forecasting climateinduced changes in the survival of Snake River spring/ summer chinook salmon. Fish Oceanogr 14 (in press)

Schwing FB, Moore C, Ralston S, Sakuma KA (2000) Record coastal upwelling in the California Current in 1999. Calif Coop Ocean Fish Investig Rep 41:148-160

Schwing FB, Murphree T, de Witt L, Green P (2002) The evolution of oceanic and atmospheric anomalies in the Northeast Pacific during the El Niño and La Niña events of 1995-2001. Progr Oceanogr 54:459-491

Strub PT, James C (2002) Altimeter-derived surface circulation in the large-scale NE Pacific Gyres. Part 2:1997-1998 El Niño anomalies. Prog Oceanogr 53:185-214

Thomas AC, Strub PT, Brickley P (2003) Anomalous satellitemeasured chlorophyll concentrations in the northern California Current in 2001-2002. Geophys Res Lett 30(15), 8022, doi: 10.1029/2003GL017409

Wheeler PA, Huyer A, Fleischbein J (2003) Cold halocline, increased nutrients and higher chlorophyll off Oregon in 2002. Geophys Res Lett 30(15), 8021, doi: 10.1029/2003 GL017395

Submitted: October 7, 2004; Accepted: March 1, 2005

Proofs received from author(s): July 21, 2005 